\title{
Attack on social and labor rights in Brazil
}

\author{
Summary \\ Since 2016, Brazil has been living with signs of a democratic rupture that ended the \\ previous virtuous cycle of economic growth with social inclusion. In addition, the \\ resumption of the neoliberal prescription has been destructive of social and labor \\ rights, concomitant with high unemployment and generalization of precarious jobs. \\ The connection of what occurs in Brazil with the more general transformations in the \\ world of work allows us to broaden the context in which current capitalism favors the \\ attack on Brazilian social and labor rights. As a result, there are reactions that seek \\ to gather forces that are not always sufficient to face the downgrading of living and \\ working conditions.
}

Keywords: state, work, politics, law, social, labor rights, economic, public goods and services, social welfare
Volume I Issue $3-2017$

\author{
Marcio Pochmann \\ Department of Economics, University of Campinas, Brazil
}

Correspondence: Marcio Pochmann, Department of Economics, University of Campinas, Brazil, Email mrcpochmann@gmail.com

Received: August 13, 2017| Published: September II, 2017

\section{Introduction}

This article focuses on the issue of the attack on social and labor rights in Brazil since the democratic rupture established in 2016. Therefore, the thematic analysis is made up of three parts, the first one related to social protection policy and Labor in central capitalism and in the periphery as in Brazil. The second describes the main transformations taking place in the world of work. In the third and last art are the propositions of social and labor rights changes and their reactions in Brazil. In the final considerations, the main founding elements of the current theme of social protection and labor in Brazil are highlighted.

\section{Social and labor protection policies}

The understanding of social protection and labor in capitalism is associated with three fundamental determinants. The first refers to the historical periodic crises of capitalism that reveal not only greater difficulties for the working class, but also opportunities for their profound reaction and restructuring. ${ }^{1-5}$ In these special moments, it is observed that the old forms of valorization of the capital signalize exhausts whereas the new forms still do not present sufficiently mature to dynamize the capitalist system as a whole. Because of this, even more sophisticated forms of exploitation of the working class are undergoing experimentation, many of which are implied in the larger financialization movement of the existing wealth stock.

The application of the new methods of intensification and extension in the use and remuneration of the workforce tests the workers' reaction capacity, even requiring the challenging repositioning of the existing institutions of organization and representation in the world of work..$^{6-9}$ In the past we have seen the repositioning of workers in the face of times of deep crisis and restructuring of world capitalism, as in the Great Depression of 1873 to 1896 that ended up being overcome by new economic expansion associated with the International Division of Labor between the production of manufactures in the countries Industrialized countries and the concentration of raw materials and food exports in agrarian countries, such as Brazil. ${ }^{10}$ Given the conservatism of the rural oligarchy prevailing in most agrarian countries, the reformist efforts of the late nineteenth century ended up being held back by the industrialized economies in the face of the new cycle of prosperity. Even so, the modality of organization of qualified workers in the trade unions, although combative and daring, little progressed in terms of raising the standard of living of the working class as a whole. Moreover, with the advancement of the mechanization process, human labor has become an appendage of urban and industrial production. It lost, therefore, the protagonism of the human work consistent with the old agrarian societies.

The result of this ended up being the installation of enormous heterogeneity within the working class, with mechanisms of social protection and labor provided by the predominantly anarcho-syndical trade unions (mutual aid funds and self-help cooperatives) to the better employed in capitalist development. Unlike the brave and under the tutelage of the trade unions, the majority of the working class remained uncontrolled, except for special moments, whose organization and manifestation were fundamentally spontaneous and disconnected from the working elite in their fierce trade unions. In the Great Depression, which began in 1929, the world of labor once again experienced a wave of unprecedented struggles until then to the capitalist system that proved capable of imposing a new cycle of prosperity, with an increase in living conditions among the working class. The formation and extension of the public fund, with the advancement of taxation on the rich and the universalization of policies for the supply of public goods and services, gave the State of social welfare the primary task of reducing inequalities, without changing the private nature of the means of production. The emergence and diffusion of the new syndicalism, as opposed to the old trade union, allowed the generalization of the labor contracts responsible for the less unequal distribution of the productivity gains of the employed. ${ }^{11}$ This new reality, although centralized in the economies of advanced capitalism, has also manifested itself in countries of late industrialization, as in Brazil. In less than five decades, some countries in different regions of the planet have become urban, with advanced industrial areas.

The installation of the system of social and labor protection and the advances, even if contained, in labor relations, provided a platform of achievements superior to the previous period of exploitation of the workers inherited from the great crisis of the end of the 19th century. Thus, employees salaried workers have a minimum regulation, capable of offering maximum working hours, limits to employer arbitrariness in hiring, dismissal and retirement. ${ }^{12}$ In short, labor achievements never previously identified in capitalist development, such as the reduction of working hours and the full employment of the labor force. In the current crisis of globalized capitalism that 
began in 2008, the system of exploitation faces new possibilities to lead a new leap in the use and remuneration of the working class. Through the unprecedented consolidation of the centralized capitalist coordination system, with articulation and decentralized integration of the production of goods and services around the world, the labor force coexists with the experimentation of increasingly sophisticated forms of labor intensification and extension.

In relation to this, we identify the experimentation of forms of greater capitalist exploitation of human labor through the advance of outsourcing and labor Uberism. ${ }^{13-15}$ At the same time, the degradation of the achievements of workers in the environment of flexibilization and deregulation of the social and labor protection system, which defies the traditional organization and representation of the interests of the employed, also leads to the successive explosion of spontaneous, disarticulated from a larger project of transformation of capitalism. The second fundamental determinant of the condition of social protection and labor refers to the different patterns of unequal and combined development of capitalism which lay the material basis by which the condition of social protection and labor can manifest itself. This is because the process of capital accumulation presupposes the existence of a dynamic center capable of unequally combining the whole of the territorial periphery that surrounds it.

In summary, the dynamic center comprises three basic functions:

i. The power of money as a medium of exchange, a store of value and international unity of account.

ii. Military power capable of imposing by force what diplomacy does not achieve by dialogue.

iii. The hegemonic capacity to produce and diffuse technical progress. In this sense, industrial and technological revolutions stand out once they reestablish the form of inter-capitalist competition and the possibility of change in the dynamic center of capitalism. An example of this can be seen since the end of the Fordist expansion cycle in the 1970s, with the emergence of a new and profound industrial and technological revolution based on the emergence of a new global actor represented by transnational corporations.

Today, no more than 500 large transnational corporations centralize control of the fragmentedly operated value system in no more than 300 territorial spaces on the planet. The monopolization of the production and distribution of wealth on a global scale increasingly makes the large transnational corporation more powerful than the National States. Only nine countries currently have a public budget comparable to that of large private monopolies around the world. ${ }^{16}$ Faced with this is the polarization between the United States and China, pointing to a possible transition in the interior of the dynamic capitalist world center. The new frontier of open capitalist expansion from Asia, whose main vector has been the rapid and considerable process of monopolizing capital through global value chains, calls into question US hegemony. ${ }^{17}$ The geographic displacement of the world dynamic nucleus historically reflects the complex problem of capitalist asymmetry arising from the relationship between the dynamic center and the set of its periphery. Whereas in the last quarter of the 19th century the long decadence of English rule began with the emergence of the second industrial revolution and the end of free competition capitalism, the Great Depression of 1929 consolidated US hegemony over Germany, defeated in the two great Wars World Cups (1914-18 and 1939-45).
Nowadays, capitalist reorganization opens up an opportunity for a new articulation between the dynamic center and the periphery. In the past, when Brazil could not imagine the next available solution, Brazil was able to build internal political convergence capable of pointing a new direction for national development against the external centrality granted by England until the 1910s and the United States in the second postwar period. In the period between the 1880s and 1930s, for example, the national effort was decisive for the new directions to appear in Brazil. ${ }^{18}$ The realization of political reforms (1881), labor (1888), in the form of government (1889) and constitutional (1891) at the end of the 19th century favored the transition to class society moved by capitalism in the heir country of the former slave society dependent on primitive primary-export mercantile economy, incapable of generalizing any form of social protection and labor.

It was also recorded an innovative political configuration from the Thirty Revolution, responsible for the unleashing of the unprecedented economic cycle of expansion conferred by the national industrialization project. ${ }^{19}$ As a result, the material conditions necessary for the installation of the social protection and labor system were inaugurated during the transition from the old and primitive agrarian society to the modern urban and industrial society, which allowed to establish the bases of the developmentalist State in Brazil. Currently, the impasse imposed by the coup continues to express a certain reaction on the part of the United States, as a decadent dynamic center in the face of the progress of Brazil's relations with the BRICs, for example. The Brazilian experience of the constitution of haughty and active foreign policy, with the emergence of the internationalization of the great national company in the years 2000 , indicated a new way of expansion in relation to the dynamic world center in formation that is based in Asia.

Finally, the third fundamental determinant of the condition of social protection and labor is related to the capacity of the State to organize, produce and sustain over time various public policies, especially social protection and labor. It is known that the main experience of building the social protection and labor system was positive during the interruption of the first wave of capitalist globalization between the 1930s and 1980s. It turns out that in the 1870s and 1920s, with the boom of the first wave of capitalist globalization led by the United Kingdom, Brazil reaffirmed its subordinate and dependent position to the former International Labor Division. At the time, the dominance of market forces over politics made the existing (Liberal and Conservative) parties in the regime of the Monarchy (1822 1889), equivalent in defense of the minimal state interference in the economy and society. ${ }^{20}$ Even with the Old Republic $(1889-1930)$, liberal principles were maintained, showing themselves insufficient to stem the high inequalities and prejudices forged by almost four centuries of slave hegemony. Identified by the elite as awkward and indolent, the basis of the social pyramid was excluded from the productive structure, increasingly occupied by the immigrant white labor force, the original basis of the old syndicalism organization. ${ }^{21}$ Any initiative to regulate the labor market, for example, was considered unconstitutional, unacceptable to be exercised by the minimum state. The social question, on account of this, continued to be treated as a police case. Only with the interregnum of the first wave of capitalist globalization in the early 20th century that more significant changes occurred in relation to social protection and labor in Brazil. In this sense, the experiences of real socialism represented by the Russian Revolution (1917), of gravity in the Great Depression of 1929, and of the tragic realization of the two great world wars, 
pursued by rearmament in the Cold War (1947-1991), the phase of gold development in capitalism regulated from the centrality of the United States throughout the second half of the twentieth century. ${ }^{22}$

In this sense, it can be seen that in Brazil, during the 1930s and 1970s, the transition from the archaic and long-lived agrarian society to the modern urban and industrial society was accompanied by reforms carried out in the spheres of developmental state organization. For example, the democratization of the political regime, the generalization of labor law, the expansion of public education, among others. All of them proved to be functional and effective in shifting the Brazilian position in the International Labor Division from mere commodity exporter in the 1920 s to the 8 th most important industrial economy in the world in 1980. All of them proved to be functional and effective in shifting the Brazilian position in the International Labor Division from mere commodity exporter in the 1920 s to the 8 th most important industrial economy in the world in 1980. Even so, the social protection and labor system was universalized, maintaining its functioning in the form of social monopolies that are inequalities of opportunity and of social ascension for a portion of the working class. Only by the Federal Constitution of 1988 and with the experience of the universal public policies in the decade of 2000 that the system of social protection and of work has advanced considerably in Brazil. But by the current capitalist restructuring imposed by the second wave of globalization led by large transnational corporations and under the financial dominance the state's capacity to sustain public policies has been contained, bringing negative repercussions not only on social protection and labor.

\section{Transformations in the world of work}

Certainly packed by a certain technological determinism and imagined leaps in the productivity of immaterial labor, a new range of promises has been forged by the ideologues of capitalist development towards the longed-for free society extended by the advancement of creative leisure, full-time education, and of containment of heteronomous work (only for survival). Penetrated increasingly by the media culture of individualism and the ideology of competition, neoliberalism continued to expand supporters in the world. With this, the prospect arose that changes in social relations would inexorably reverberate over the workings of the labor market. ${ }^{24-26}$ With the demographic transition, new expectations were being presented. Advertising for raising life expectancy to close to 100 years of age, as an example, should open the door to the postponement of entry into the labor market for youth to complete higher education, to study throughout life and to work with weekly 12 hours.

The new post-industrial society would thus be offering a civilizing standard never reached by the capitalist mode of production and distribution. And under this mantle of promises of greater liberation of the workman by the struggle of survival (heteronomous work) by postponing the age at the entrance to the labor market only after the fulfillment of higher education, as well as the educational offer throughout the life, which neoliberal rationalism was constituted. In a sense, it has brought the understanding that the emptying of the relative weight of the national economy from the primary (agricultural and livestock) and secondary sectors (industry and civil construction) would consecrate superior expansion of the tertiary sector (services and commerce). In short, the post-industrial society was to be the protagonist of achievements beyond the bounds of what had been possible since the 1930s, possible without struggle, because it was contrary to social class in a society founded on the individual who was competitive and promoted his own life insurance and no longer dependent on the State. ${ }^{27}$

These promises, however, did not become effective, so little resulted from the imagined neoliberal modernization. In the full course of the transition to the service society, labor market insertion needs to be gradually postponed, possibly to join the labor activity only after the completion of higher education, aged over 22 years, and synchronized exit of the labor market for the advancement of inactivity. All this accompanied by a reduced working day, which would allow the heteronomous work to correspond to no more than $25 \%$ of the time of human life. ${ }^{28}$ In this sense we can identify a line perspective of human work associated with class struggles and to the greater capacity of public performance through the democratic State. It should be pointed out that in the old agrarian society, the beginning of work occurred from 5 to 6 years of age to prolong to almost death, with extremely long working hours (14 to 16 hours a day) and without rest periods, such as holidays and paid inactivity (pensions and pensions). For someone who managed to reach 40 years of age, having started work at age 6 , for example, the time committed only to work activities absorbed about $70 \%$ of his entire life.

In industrial society in the labor market was delayed for the 16 years of age, guaranteeing the employed, from there, the access to weekly rest, vacations, pensions and pensions coming from the public regulation of work. Thus, someone entering the job market after the age of 15 and remaining active for another 50 years would possibly have more years of paid inactivity (retirement and pension). Thus, about $50 \%$ of the time of the whole would be committed to the exercise of heteronomous work. The rest of the life cycle, not compromised by work and survival, should be associated with the reconstruction of sociability, study, and training, increasingly demanded by the new organization of internationalized production and distribution.

This is because, given the high and constant gains of productivity, it has become possible to reduce the weekly working time from something around 40 hours to no more than 20 hours. To a certain extent, the transition between urban-industrial and post-industrial societies would tend not to separate labor time from non-work more clearly and rigidly, and could generate a greater mixture between the two, with more intensity and risk of extended longevity of the journey In addition to the traditional place of effective exercise of work. Within this context, the relationship between heteronomous working time and life would be relocated to new bases. ${ }^{29-31}$ In general, the functioning of the labor market, related, over time, to a variety of typical and atypical forms of use and remuneration of surplus workforce derived from internal and external migratory movements without controls, as pointed out originally by authors who imagined superior the passage of the old urban and industrial society to the one of services (tertiary).

But after almost four decades of generation of the neoliberal promises aimed at building a higher society, there is, on the contrary, the strengthening of undeniable signs of regression within the society of capital advancing in Brazil. From the progress registered in the construction of a social structure mediated by social and labor policies since the 1930s, the return of the strong social polarization is observed at the beginning of the 21 st century. On the one hand, the degradation of the inherited social structure of Fordist industrialization has deconstituted a large portion of the middle class, strengthening the expansion of the new precariat in the working class as a whole. ${ }^{32}$ On the other hand, the concentration of significant gains of wealth and income in the minority segment of the population generates 
unimaginable social context, where only the contained part of society holds growing portions of wealth. In more than three decades of predominance of neoliberal regulation of capitalism, the promises of the construction of superior civilizational standard are undone. The advances that have been made have been for a few, while the observed setbacks serve many.

\section{Deconstruction and resistance}

The confirmation of the return to the phase of deregulation and flexibilization of social and labor policies imposes a new pattern of exploitation to the working class. With the decadence of the Fordist industrialization and regulation pattern, Brazil follows the largest movement of the wage society, especially that which is shaped by the greater proximity between the base and the summit of the social structure. Thus, the transition from the traditional salaried middle classes and industrial workers to the unprecedented and extensive precarious, with an important social polarization permeated by the spontaneity of increasingly anarchic characteristics. Concomitant with the new communication technologies, social and labor mobilizations run above the sectoralization and fragmentation of the traditional trade union organization, which generates estrangement between existing structures and spontaneous forms of social and political mobilization. ${ }^{33}$

The vacuum provided by deindustrialization has been occupied by the so-called service society, which is, in this sense, a new perspective of structural change in the world of work. This change has made the pattern of labor exploitation ever greater in the face of the depletion of social and labor regulation and the promises of modernity by the neoliberal prescription that are not realized. The long journey to bring about the regulation of the world of work in Brazil seems to have its days counted against the green light granted by the interdiction of the democratically elected government in $2014 .{ }^{34}$ With the prevention of President Dilma in 2016, a series of projects liberalizing social legislation And Labor Party that had been imprisoned since the rise in 2003 of the governments led by the Workers' Party came to be unveiled.

With this, Brazil began to live with a fourth wave of flexibilization of the social and labor from the 1930s, when the transition from the old agrarian to the urban and industrial society began to be consolidated. This is because the constitution of the national labor market resulted from a slow transition of 80 years, begun in 1850 , with the end of the slave trade and the implementation of the land law, completed in 1930, overcoming the condition of regional markets. ${ }^{35}$ Even before the passage of the Empire to the Republic in 1889, labor market regulation ended up being postponed in the face of the prevalence of the "free labor" situation defined by the first republican constitution in 1891. Not even the 1926, of the constitutional amendment 29, which made it possible for the National Congress to legislate on the subject of labor, altered the liberal perspective of maintaining the state outside of social and labor regulation.

From the Thirteenth Revolution, however, labor regulation became a novelty, diffused fragmented, according to pressure located in the strongest categories and best inserted in capitalist development. After a decade of clashes, with the implementation of scattered laws regulating the emergence of salaried employment, the Consolidation of Labor Laws (CLT) was implemented in 1943, under the authoritarian political regime of Estado Novo (1937-1945). Even so, most workers were excluded from the labor code in the face of the conservative liberal opposition of rural landowners, a former dominant force in the Old Republic (1889 - 1930). Until 1963, with the approval of the Statute of the Rural Worker, which opened the possibility of slow and gradual incorporation of rural labor, CLT returned only to urban labor relations. By the Federal Constitution of 1988, that is, 45 years after the implementation of the CLT, rural workers have equal rights to urban employees, although they still have segments of the employed without access to social and labor regulation. In the 1940s, for example, the CLT barely reached $10 \%$ of the employed, while today it has surpassed 2/3 of the workers. With the recession and setbacks of the current coup government, the retreat of social and labor protection is advancing. ${ }^{36}$ The approval of the most recently unleashed neoliberal reforms will further increase the degree of exclusion in Brazil.

A first wave of flexibilization of the social and labor legislation passed since the second half of the 1960s, with the rise of the Military Dictatorship (1964 - 1985), was highlighted. At the time, the implementation of the FGTS, for example, not only interrupted the trajectory of stability in employment, but inaugurated a huge turnaround in the contraction and dismissal of the Brazilian labor force. The turnover rate of about 15 percent of the workforce per year in the 1960s rapidly accelerated, approaching half of the country's formal jobs. Thus, the generalization of the employer's procedure to replace higher-paid employees by lower paid workers. In the wage policy in force between 1964 and 1994, the result was, in general, the loss of purchasing power of workers' income, especially in the real value of the minimum wage, ${ }^{37}$ which serves the basis of the country's distributive pyramid. Faced with the significant expansion of labor productivity, wages lost the race for inflation, which contributed even more to the worsening of income inequality in Brazil.

This second wave of flexibilization has been characterized by shifting the evolution of labor income from the accelerated productivity behavior, bringing, consequently, the prevalence of a low-wage industrial economy. At the same time, there is a great inequality between labor income between high and low wages and between income from work and other forms of property income (interest, profits, rents and others). The third wave of flexibilization of labor relations can be observed in the 1990s, with the domination of governments with neoliberal orientation. ${ }^{38}$ In this way, we saw the generalization of liberalization measures for the hiring of workers by modalities below the orientation established by the CLT. Among them, the emergence of outsourcing of contracts, in full massification of unemployment and precariousness of labor relations.

Since the mid-2010, however, a fourth wave of flexibilization of social and labor laws has been unleashed. With the recent partial defeat of the workers imposed by the Chamber of Deputies for the approval of the legislation for outsourcing, the septuagenarian CLT again threatens to be demoted. ${ }^{39}$ The current bill of the outsourcing bill still to be evaluated by the Federal Senate and that counts with the anticipated support of the Temer government, lies in it with the prospect of generalization of labor Uberism at the beginning of the 21 st century, as well as the destruction of the collective bargaining system of labor and social and labor protection. This is because the UBER's way of organizing and remunerating the workforce is increasingly distanced from the regularity of formal employment, often accompanied by the guarantee of social and labor rights.

Experiments of Uberism of labor advance in a diversified form in the supranational space. They began with initiatives in individual 
transportation through widespread deregulation in the provision of taxi systems for applications resulting from information and communication technologies until they currently reach zero-hour contracts whose worker remains at home awaiting the demand for their workforce From anywhere in the world. All this aside from national labor regulation, as a result of the generalization of new information and communication technologies amid the enormous surplus of labor. The collapse of organizations representing workers' interests (associations, unions and parties) runs as a general consequence of this new phase of intensification of labor exploitation. ${ }^{40}$

As labor and social rights are increasingly being treated by employers and their machines of agitation and propaganda as fundamentally costly, direct contracting without social and labor rights frees up the greater individual competition among the workers themselves for the bosses. Trade unions are left out of the negotiation, further contributing to emptying the degree of organization in its own social and territorial base. By relying more and more on directly received income, with no more than the historical indirect salary (vacations, holidays, pensions, etc.), public funds to finance the social security system weaken, when they do not contribute to the prevalence of Rentismo. ${ }^{41}$ The containment of outsourcing, as a result, could stall the diffusion trajectory of the Uber mode of precariousness of labor contracting.

\section{Conclusion}

For a country that is slow to pursue its sustainable development, one of the advantages that arises would be the possibility of reversing the priorities that had been assumed up to now. Faced with the current capitalist restructuring imposed by the second wave of globalization conducted by large transnational corporations and under financial dominance, social and labor protection has been prominent in debates both within international competition and in the definition of development options for nations. An example of this has been the logic of the business world invading social and labor reform decisions, capable of deconstructing rights and restricting trade union activity.

The resumption of Brazilian development, in this sense, requires the revision of the neoliberal perspective based on the production and diffusion of the individual, non-classist way of the world. On the one hand, because the degradation of the social structure inherited from Fordist industrialization has deconstituted a large part of the middle class, as well as strengthening the expansion of the new precariousness of the working class as a whole. ${ }^{42}$ On the other hand, the concentration of significant wealth and income gains in the minority segment of the population generates an unimaginable social context, where only a contained part of the population now has more wealth than most of the inhabitants of Brazil. In more than three decades of the predominance of neoliberal regulation of capitalism, the promises of the construction of a higher civilizational standard are undone, since the advances have been for few and the generational setback for many.

In the current crisis of globalized capitalism, which began in 2008 , the exploitation system is faced with new possibilities to lead a new leap in the use and remuneration of the working class. The unprecedented consolidation of the centralized capitalist coordination system, with articulation and decentralized integration of the production of goods and services around the world, exposes the workforce to increasingly sophisticated forms of exploitation. Peripheral protagonism reveals an unprecedented opportunity for substantial change in the world order, with prospects of reducing the brutal degree of inequality between countries and social classes. But this still presupposes global convergence and coordination still nonexistent these days. Nor is the current Brazilian government prepared to account for the perspectives opened at the beginning of the twenty-first century. ${ }^{43}$ On the contrary, the democratic rupture that took place after 2016 imposed the predominance of a deconstructive agenda of social and labor rights. Because of this, the political turbulence must follow its turn, possibly accelerating the maturation of another convergence for the Brazilian economy and society. The reactions on the part of the workers have been important, although not always enough to stop the advance of the neoliberal prescription.

\section{Acknowledgements}

None.

\section{Conflict of interest}

The author declares no conflict of interest.

\section{References}

1. Agliettà M. Regulación y crisis del capitalismo. México: Siglo XXI; 1979. $52 \mathrm{p}$

2. Akyüz Y. Impasses do desenvolvimento. Novos Estudos CEBRAP. Brazil: SciELO; 2005. 72 p.

3. Alier J. El ecologismo de los pobres: conflictos ambientales y lenguajes de valoración. Spain: Icaria Editorial; 2005.

4. Altvater E. O preço da riqueza: Pilhagem ambiental e a nova (des)ordem mundial. Brazil: UNESP; 1995. 334 p.

5. Anderson C. Makers: a nova revolução industrial. Actual, Portugal; 2013. $276 \mathrm{p}$.

6. Aron R. Dezoito lições sobre a sociedade industrial. Brazil: UNB/MF; $1981.140 \mathrm{p}$.

7. Beck U. Un nuevo mundo feliz: la precariedad del trabajo em la era de la globalización. Argentina: Paidós; 2000. 344 p.

8. Beinstein J. El Capitalismo senil. Record, Rio de Janeiro, Brazil; 2001. $283 \mathrm{p}$.

9. Bell D. O advento da sociedade pós-industrial. Brazil: Cultrix; 1973. $544 \mathrm{p}$.

10. Belluzzo L. Os Antecedentes da tormenta: origens da crise global. Brazil: UNESP; 2009. 312 p.

11. Boltanski L, Chiapello E. O novo espirito do capitalismo. Brazil: Martins Fontes; 2009. 683 p.

12. Coates D. Models of capitalism. UK: Polity Press; 2000. p. 663-664

13. Cunha L. Educação e desenvolvimento social no Brasil. Brazil: Francisco Alves; 1980

14. David P, Reder M. Nations and Household in Economic Growth. 1st ed. USA: Academic Press; 1974. 428 p.

15. Davis S, Jon Lukomnik, David PittWatson. The New Capitalists: How Citizen Investors Are Reshaping the Corporate Agenda. USA: HBSP; 2006. 320 p.

16. Dieese. A situação do trabalho na primeira década dos anos 2000. Brazil: Dieese; 2012. 406 p.

17. Dreifuss R. Transformações: matizes do século XXI. Brazil: Vozes; 2004.

18. Freiden J. Capitalismo global. Madrid, Spain; 2007. 341 p. 
19. Frigotto G. Educação e a crise do capitalismo real. 4th ed. Brazil: Cortez; 2000. 118 p.

20. Glattfelder J. Decoding Complexity: Uncovering Patterns in Economic Networks. Switzerland: Springer; 2012. 264 p.

21. Kumar K. Da sociedade pós-industrial à pós-moderna: novas teorias sobre o mundo contemporâneo. 2nd ed. Brazil: Zahar; 1997. 260 p.

22. Lojikine J. L'adieu à la classe moyenne. Paris : La Dispute; 2005. 246 p

23. Maddison A. Perspectives on Global Economic Progress and Human Development. Annual Symposium, 1999. 22 p.

24. Marx K. Grundrisse. Brazil: Boitempo; 2011. 826 p.

25. Masi D. O futuro do trabalho: fadiga e ócio na sociedade pós-industrial Brazil: UNB/JOE; 1999.

26. Mazoyer M, Roudart L. História das agriculturas no mundo. Brazil: UNESP; 2009. 569 p.

27. Melman S. Depois do capitalismo. Brazil: Futura; 2002. 693 p.

28. Milberg W, Winkler D. Outsourcing Economics: Global Value Chains in Capitalist Development. UK: Cambridge University Press; 2013. 376 p.

29. Narodowski P, Lenicov M. Geografia económica mundial: um enfoque centro-periferia. Argentina: UNM; 2012. 408 p.

30. Oconnor M. Is capitalism sustainable? Political Economy and the Politics of Ecology. New York: Guilfort Press; 1994.

31. Perspectives dudéveloppement mondial. Italy: Ocde; 2010.
32. Pochmann M. O emprego na globalização: a nova divisão internacional do trabalho e os caminhos que o Brasil escolheu. Brazil: Boitempo; 2001. $152 \mathrm{p}$.

33. Pochmann M. Classes do trabalho em mutação. Brazil: Revan; 2012 $128 \mathrm{p}$.

34. Pochmann M. A vez dos intocáveis no Brasil. Português: Ver Curiosidades; 2014. 143 p.

35. Reich R. O trabalho das nações. Brazil: Educator; 1994. 575 p.

36. Reich R. O futuro do sucesso: o equilibrio entre o trabalho e qualidade de vida. Brazil: Manole; 2002. 313 p.

37. Reich R. Super capitalism o. Campus, Rio de Janeiro, Brazil; 2007.

38. Rifkin J. The end of work. USA: Hardcover; 1995. 350 p.

39. Rothkopf D. Super class: The Global Power Elite and the World They Are Making. UK: Federal News Service; 2008. 18 p.

40. Santos N, Gama A. Lazer: da conquista do tempo à conquista das práticas. Portugal: IUC; 2008. 271 p.

41. Silva A. Desenvolvimento, indústria e comércio na era da globalização. Brazil: IE/Unicamp; 2007.

42. Standing G, Cristina A. O precariado: a nova classe perigosa. Brazil Autêntica; 2013.

43. Stevenson B, Wolfers J. Economic Growth and Subjective Well-Being: Reassessing the Easterlin Paradox. UK: NBER Working paper; 2008. $102 \mathrm{p}$ 